Gut, 1973, 14, 289-292

\title{
Gastric mucosal morphology and faecal blood loss during ethanol ingestion
}

\author{
V. P. DINOSO, Jr, H. MESHKINPOUR, AND S. H. LORBER \\ From the Department of Medicine, Temple University School of Medicine, Philadelphia, Pennsylvania
}

SUMmARY The faecal blood loss of six alcoholic subjects with normal gastric mucosa, six with superficial gastritis, and six with atrophic gastritis was studied before and during ingestion of $40 \%$ $\mathrm{v} / \mathrm{v}$ ethanol using ${ }^{51} \mathrm{Cr}$-tagged red blood cells. No significant change in faecal blood loss was observed in the normal mucosa and superficial gastritis groups but all subjects with atrophic gastritis had significant increases of faecal blood loss during ethanol ingestion. These observations suggest that gastric mucosal morphology may be an important determinant of gastric mucosal bleeding during the ingestion of alcohol.

The role of ethanol in the pathogenesis of acute erosive gastritis and bleeding is controversial and poorly understood. A study employing gastroscopy has indicated a very high incidence of erosive gastritis following heavy ethanol ingestion (Palmer, 1954) but investigation of faecal blood loss, using ${ }^{51} \mathrm{Cr}$-tagged red blood cells, in apparently normal subjects exposed to ethanol did not demonstrate increased loss of blood in the stools (Bouchier and Williams, 1969; Goulston and Cooke, 1968). There is some evidence that chronic gastritis may predispose to upper gastrointestinal bleeding during heavy ethanol ingestion (Winawer, Bejar, McCray, and Zamcheck, 1971). However, in a recent survey no association between alcohol ingestion and upper gastrointestinal haemorrhage was observed (Needham, Kyle, Jones, Johnston, and Kerridge, 1971). Differences in the histological status of the gastric mucosa from one study population to another might have accounted, in part, for the divergent findings observed in previous investigations. To determine the possible influence of the underlying morphology of the gastric mucosa on its response to ethanol, we studied faecal blood loss before and during the ingestion of ethanol in alcoholics with different histological conditions of the gastric mucosa.

\section{Materials and Methods}

Eighteen alcoholics were studied. Six had normal

Received for publication 4 January 1973. mucosa and normal maximal acid output (MAO), six had superficial gastritis with normal or low MAO, and six had atrophic gastritis with low or absent MAO. The morphological status of the gastric mucosa was determined from biopsy specimens obtained from the antrum and body of the stomach by suction biopsy under fluoroscopic observation. The criteria utilized by previous investigators in this field (Joske, Finch, and Wood, 1955) were used in the histological grading of our biopsy samples. Gastric secretion of acid was quantitated using histalog as a stimulant in a dose of $1.5 \mathrm{mg} / \mathrm{kg}$ intramuscularly. The range of values for MAO adjusted to weight, age, and sex, reported by Blackman, Lambert, Thayer, and Martin (1970), was used to classify the status of acid secretion.

All studies were carried out either in the Clinical Research Center of Temple University Hospital, the GI Clinic, or the laboratories of the Department of Nuclear Medicine. Before investigation, all subjects had a complete blood count, complete liver function tests, prothrombin time, partial thromboplastin time, platelet count, and bleeding time. During the studies of faecal blood loss, the coagulation profiles (vide supra) were determined before and after the period of ethanol administration. In addition, to detect potential bleeding lesions, all subjects were subjected to upper gastrointestinal series, barium enema, oesophagogastroduodenoscopy, and proctosigmoidoscopy.

On the first day of the study, $20 \mathrm{ml}$ of the subject's venous blood was incubated with $300 \mu \mathrm{c}$ of ${ }^{51} \mathrm{Cr}$ in 
ACD solution (Squibb) for 45 minutes at room temperature, washed with normal saline three times, and then reinjected intravenously. All subjects were fed the regular hospital diet. A control period of three days was followed by an ethanol period of three days. During the ethanol period, $200 \mathrm{ml}$ of $40 \% \mathrm{v} / \mathrm{v}$ ethanol in orange juice was ingested from 8 to 10 $\mathrm{pm}$ at a rate of $50 \mathrm{ml}$ every 30 minutes. Stools were collected in plastic containers (Dolbey Scientific Co) containing 20 glass beads $(5 \mathrm{~mm}$ diameter, Fischer Scientific Co) and distilled water to the halfway mark. The stools were shaken vigorously before counting. The glass beads aided in the separation of the stools into small particles. At the end of each 24-hr stool collection, distilled water was added up to $1 \mathrm{~cm}$ below the top and sealed. Venous blood was collected in heparinized test tubes at the midpoint of each 24-hour collection period. Blood and stool samples were counted in an open-well Baird-Atomic scintillation counter in the plastic containers. To reduce background radioactivity, each container was completely enclosed by a $1 / 2$ inch thick lead shield. To count the radioactivity of the blood samples, $5 \mathrm{ml}$ was pipetted into similar plastic containers containing the same number of glass beads and diluted to the same volume as the stool samples with distilled water. Both blood and stool samples were counted for 30 minutes and a minimum of 10000 counts was obtained. Net counts were obtained by subtracting background counts from sample counts. Faecal blood loss in millilitres per 24 hours was calculated by dividing the net count of a 24-hour stool sample by the count of $1 \mathrm{ml}$ of venous blood obtained the same day.

The Student $t$ test for paired and unpaired data was used to analyse the level of significance of the difference between the means of the ethanol and control periods in each group and during the control period between groups, respectively.
Results

The mean age in years for the different histological groupings was $40 \cdot 5,38 \cdot 1$, and 45 for the group with normal mucosa, superficial gastritis, and atrophic gastritis, respectively. The mean bleeding time, prothrombin time, partial thromboplastin time, and platelet count are shown in table I. There were no essential differences in these bleeding parameters among the three histological groups.

The mean blood loss during the control period of the group with atrophic gastritis was significantly higher $(P<0.005)$ compared to the groups with superficial gastritis or normal mucosa. There was no significant difference in the mean blood loss between the group with superficial gastritis and subjects with a normal mucosa during the control period.

There was no significant increase of blood in the stools of subjects with normal mucosa during the period of ethanol ingestion compared to the control period (table II). Although one subject with superficial gastritis had a slight increase during the ethanol period, the mean blood loss for the entire group during the ethanol period was not statistically different from that observed during the control period. In the atrophic gastritis group, all subjects had increases of faecal blood loss during the ethanol period. The mean for the whole group during the ethanol period was statistically higher $(\mathrm{P}<0.01)$ than that observed during the control period.

\section{Discussion}

Our findings indicate that the initial morphology of the gastric mucosa is an important determinant of the gastric mucosal response to ethanol. Previous studies regarding the role of ethanol on gastric mucosal bleeding have been conflicting. Gastroscopic and necropsy studies in man (Palmer, 1954;

\begin{tabular}{|c|c|c|c|c|}
\hline Group & $\begin{array}{l}\text { Bleeding Time } e^{1} \\
(\text { min })\end{array}$ & $\begin{array}{l}\text { Prothrombin Time } \\
\text { (sec) }\end{array}$ & $\begin{array}{l}\text { Partial Thromboplastin } \\
\text { Time }^{3} \\
\text { (sec) }\end{array}$ & Platelet Count \\
\hline $\begin{array}{l}\text { A Normal Mucosa } \\
\text { Mean } \\
\text { Range }\end{array}$ & $\begin{array}{l}4 \cdot 3 \\
4 \cdot 0-6 \cdot 0\end{array}$ & $\begin{array}{l}11 \cdot 1 \\
9 \cdot 3-12 \cdot 0\end{array}$ & $\begin{array}{l}31 \cdot 5 \\
27 \cdot 5-34\end{array}$ & $\begin{array}{l}218000 \\
158000-306000\end{array}$ \\
\hline $\begin{array}{l}\text { B Superficial Gastritis } \\
\text { Mean } \\
\text { Range }\end{array}$ & $\begin{array}{l}3 \cdot 6 \\
2 \cdot 5-5 \cdot 0\end{array}$ & $\begin{array}{l}11 \cdot 6 \\
11 \cdot 0-12 \cdot 9\end{array}$ & $\begin{array}{l}32 \cdot 2 \\
28 \cdot 8-36 \cdot 0\end{array}$ & $\begin{array}{l}278667 \\
170000-425000\end{array}$ \\
\hline $\begin{array}{l}\text { C Atrophic Gastritis } \\
\text { Mean } \\
\text { Range }\end{array}$ & $\begin{array}{l}3 \cdot 83 \\
2 \cdot 5-5 \cdot 5\end{array}$ & $\begin{array}{l}11.98 \\
11 \cdot 5-12.4\end{array}$ & $\begin{array}{l}34 \cdot 64 \\
31 \cdot 0-38 \cdot 5\end{array}$ & $\begin{array}{l}218250 \\
157000-318000\end{array}$ \\
\hline
\end{tabular}

Table I Coagulation profile of the three histological groups

${ }^{1}$ Ivy bleeding time, $\mathrm{n}=\mathbf{2 - 7}$ minutes

QQuick's one-stage prothrombin time

$s^{3} n=<40$ seconds 


\begin{tabular}{|c|c|c|}
\hline Histological Group & Control Period 1 & Ethanol Period ${ }^{1}$ \\
\hline $\begin{array}{l}\text { A Normal Mucosa } \\
1 \text { J.M. } \\
2 \text { J.C. } \\
3 \text { S.B. } \\
4 \text { R.B. } \\
5 \text { A.P. } \\
6 \text { J.B. }\end{array}$ & $\begin{array}{l}0.08 \\
0.16 \\
0 \cdot 15 \\
0.03 \\
0 \cdot 17 \\
0.04\end{array}$ & $\begin{array}{l}0 \cdot 38 \\
0 \cdot 09 \\
0 \cdot 12 \\
0 \cdot 10 \\
0 \cdot 55 \\
0 \cdot 31\end{array}$ \\
\hline Mean (SEM) 2 & $0.105 \pm 0.026$ & $0.258 \pm 0.076$ \\
\hline $\begin{array}{ll}\text { B } & \text { Superficia Gastritis } \\
1 & \text { J.P. } \\
2 & \text { H.B. } \\
3 & \text { J.P. } \\
4 & \text { S.R. } \\
5 & \text { A.B. } \\
6 & \text { R.G. }\end{array}$ & $\begin{array}{l}0.03 \\
0 \cdot 17 \\
0 \cdot 18 \\
0 \cdot 17 \\
0 \cdot 10 \\
0 \cdot 25\end{array}$ & $\begin{array}{l}0.43 \\
0.27 \\
0.005 \\
0.15 \\
0 \cdot 10 \\
0.80\end{array}$ \\
\hline Mean (SEM) & $0.150 \pm 0.031$ & $0.459 \pm 0.169$ \\
\hline Mean (SEM) & $0.553 \pm 0.083$ & $1.765 \pm 0.289$ \\
\hline
\end{tabular}

Table II Mean daily faecal blood loss (in ml per 24 hours)

${ }^{1}$ Mean of three days

'Standard error of the mean

Winawer et al, 1971, Dinoso, Meshkinpour, and Lorber, 1972; Williams, 1956) and studies in experimental animals (Williams, 1956; Dinoso, Chey, Siplet, and Lorber, 1970) suggested a possible causal relationship between haemorrhagic gastritis and exposure to ethanol. However, faecal blood loss studies, utilizing ${ }^{51} \mathrm{Cr}$-tagged red blood cells in normal human volunteers, did not indicate significant gastrointestinal bleeding resulting from the ingestion of ethanol (Bouchier and Williams, 1969; Goulston and Cooke, 1968). The dose of ethanol employed, the concentration of ethanol administered, or the variable subject populations in terms of status of the gastric mucosa are possible factors which could account for the differences in results reported by these earlier investigators. In a recent study (Winawer et al, 1971) it was suggested that upper gastrointestinal bleeding resulting from ethanol ingestion is associated with either superficial or atrophic gastritis. In our series, all subjects with atrophic gastritis were observed to have increased faecal blood loss during ingestion of ethanol.

Platelet function, which was implicated recently as an important factor in most episodes of upper gastrointestinal bleeding(Atik, 1972), was not studied. However, abnormalities in platelet count, prothrombin time, partial thromboplastin time and bleeding time were not observed either before or after the administration of ethanol, and bleeding time has been shown recently to reflect platelet function (Harker and Slichter, 1972). Lesions of the gastrointestinal tract with a potential for bleeding, such as oesophageal varices, oesophagitis, gastric and duodenal ulcer, colonic lesions, and haemorrhoids were excluded by a complete examination of the gastrointestinal tract before including individuals in the study group. None of our subjects had clinical or biochemical evidence of cirrhosis.

The biological properties of the gastric mucosa with atrophic gastritis, which influence the increased loss of red blood cells under basal conditions and which predispose it to the development of erosions and haemorrhage following exposure to $40 \%$ ethanol, remain to be elucidated. However, it is not unreasonable to speculate, on the basis of the mucosal biopsy findings of the mucosa (Dinoso et al, 1972), that ethanol may have a direct toxic effect on the superficial lining cells causing them to undergo necrosis and exfoliation. Such changes would expose the capillaries in the lamina propia to similar damage. In biopsy studies of the Heidenhain pouch of dogs performed serially, we demonstrated exfoliation of superficial lining cells, and congestion and oedema of the lamina propia following exposure to 20 and $40 \%$ ethanol for 30 minutes (Dinoso et al, 1970). It is well known also that an atrophic mucosa is much thinner than a normal mucosa (Palmer, 1954; Joske et al, 1955). Using the method of Croft and Lubran (1965) of estimating the rate of exfoliation of the surface cells of the gastric mucosa, we found 
that the rate of cell exfoliation in subjects with atrophic gastritis is four times greater than that of subjects with normal mucosa or superficial gastritis (unpublished observations). Similar observations were made previously by Croft, Pollock, and Coghill (1966). The inherent thinness and increased tendency of the epithelial lining cells to exfoliate in a mucosa with atrophic gastritis could contribute to the increased loss of red blood cells during the basal state as well as to the development of mucosal erosions and bleeding upon exposure to ethanol.

We wish to express our gratitude to Dr David Charkes of the Department of Nuclear Medicine for supervising the faecal blood loss studies, and to Mrs Shu-Hua Hsiao for processing the gastric mucosal biopsies.

This study was supported by U.S. Public Health Research grant no. NIMH 1 R01 MH21529-01, grant (RR-349) from the General Clinical Research Centers Program of the Division of Research Resources, National Institute of Health, and by grants from the William $H$. Rorer, Inc, Fort Washington, Pennsylvania and License Beverage Industries, New York City.
References

Atik, M. (1972). Platelet dysfunction in massive gastrointestinal bleeding. Gastroenterology, 62, 719.

Blackman, A. H., Lambert, D. L., Thayer, W. R., and Martin, H. F. (1970). Computed normal values for peak acid output based on age, sex and body weight. Amer. J. dig. Dis., 15, 783-789.

Bouchier, I. A. D., and Williams, H. S. (1969). Determination of faecal blood-loss after combined alcohol and sodium-acetyl salicylate intake. Lancet, 1, 178-180.

Croft, D. N., and Lubran, M. (1965). The estimation of deoxyribonucleic acid in the presence of sialic acid: application to analysis of human gastric washings. Biochem. J., 95, 612-620.

Croft, D. N., Pollock, D. J., and Coghill, N. F. (1966). Cell loss from human gastric mucosa measured by the estimation of deoxyribonucleic acid (DNA) in gastric washings. Gut, 7, 333-343.

Dinoso, V. P., Chey, W. Y., Siplet, H., and Lorber, S. H. (1970). The effects of ethanol on the gastric mucosa of the Heidenhain pouch of dogs. Amer. J. dig. Dis., 15, 809-817.

Dinoso, V. P., Meshkinpour, H., and Lorber, S. H. (1972). Studies on the acute effects of ethanol on the gastric mucosa in man. Gastroenterology, 62, 843.

Goulston, K., and Cooke, A. R. (1968). Alcohol, aspirin, and gastrointestinal bleeding. Brit. med. J., 4, 665-668.

Harker, L. A., and Slichter, S. J. (1972). Bleeding time as screening test to evaluate platelet function. New Engl. J. Med., 287, 155159.

Joske, R. A., Finch, E. S., and Wood, I. J. (1955). Gastric biopsy: a study of 1000 consecutive successful gastric biopsies. Quart. J. Med., 24, 269-294.

Needham, C. D., Kyle, J., Jones, P. F., Johnston, S. J., and Kerridge, D. F. (1971). Aspirin and alcohol in gastrointestinal haemorrhage. Gut, 12, 819-821.

Palmer, E. D. (1954). Gastritis: a re-evaluation. Medicine (Baltimore), $33,199-290$.

Williams, A. W. (1956). Effects of alcohol on gastric mucosa. Brit. med. J., 1, 256-259.

Winawer, S. J., Bejar, J., McCray, R. S., and Zamcheck, J. (1971). Hemorrhagic gastritis. Importance of associated chronic gastritis. Arch. intern. Med., 127, 129-131. 